\title{
Ocean acidification as one of multiple stressors: growth response of Thalassiosira weissflogii (diatom) under temperature and light stress
}

\author{
Uta Passow ${ }^{1, *}$, Edward A. Laws ${ }^{2}$ \\ ${ }^{1}$ Marine Science Institute, University of California Santa Barbara, Santa Barbara, CA 93106, USA \\ ${ }^{2}$ Department of Environmental Sciences, School of the Coast and Environment, Louisiana State University, Baton Rouge, \\ LA 70803, USA
}

\begin{abstract}
Future shifts in phytoplankton composition and productivity are anticipated given that continuing changes are expected in environmental conditions such as temperature, the partial pressure of $\mathrm{CO}_{2}\left(p \mathrm{CO}_{2}\right)$ and light climate, all of which regulate phytoplankton communities and their physiology through bottom-up control. Culture experiments revealed that future (elevated) $p \mathrm{CO}_{2}$ had no effect on Thalassiosira weissflogii in the absence of environmental stressors, whereas growth rates drastically decreased under future $p \mathrm{CO}_{2}$ when cells were grown under light and temperature stress. Reduction in growth rates and a smaller decline in cellular photosynthesis under high $p \mathrm{CO}_{2}$ were associated with 2- to 3-fold increases in the production of transparent exopolymer particles (TEP) and in the cell quotas of organic carbon, as well as a similar decrease in the C:chl a ratios. Results suggest that under light- and temperature-stressed growth, elevated $p \mathrm{CO}_{2}$ led to increased energy requirements, which were fulfilled by increased light harvesting capabilities that permitted photosynthesis of acclimatized cells to remain relatively high. This was combined with the inability of these cells to acclimatize their growth rate to sub-optimal temperatures. Consequently, growth rate was low and decoupled from photosynthesis, and this decoupling led to large cell sizes and high excretion rates in future $p \mathrm{CO}_{2}$ treatments compared to ambient treatments when growth temperature and light were sub-optimal. Under optimal growth conditions, the increased energy demands required to re-equilibrate the disturbed acid-base balance in future $p \mathrm{CO}_{2}$ treatments were likely mediated by a variety of physiological acclimatization mechanisms, individually too small to show a statistically detectable response in terms of growth rate, photosynthesis, pigment concentration, or excretion.
\end{abstract}

KEY WORDS: Thalassiosira weissflogii - Cell characteristics · Growth · Ocean acidification · Light limitation $\cdot$ Temperature limitation $\cdot$ Multi-stressor response

\section{INTRODUCTION}

Average environmental conditions are expected to continue to change in the next decades, as increased atmospheric $p \mathrm{CO}_{2}$ leads to both ocean acidification and rising temperatures in the surface ocean. Rising temperatures alter the depth of the mixed layer, thereby impacting light and nutrient availability to phytoplankton. The productivity and composition of marine phytoplankton are frequently bottom-up controlled, meaning that environmental growth conditions

\footnotetext{
*Corresponding author: uta.passow@lifesci.ucsb.edu
}

largely drive phytoplankton abundance, physiological characteristics, and diversity. Shifts in phytoplankton composition and productivity are likely to impact food web structure and biochemical cycles (Antoine et al. 2005, Boyce et al. 2010, Boyd et al. 2010).

Environmental growth conditions are considered stressors when outside the optimal growth range of a species, and thus elicit responses that include decreased growth or photosynthesis. The possible responses of an organism that experiences simultaneous stressors include (1) no interactions, (2) inter-

๑) The authors 2015. Open Access under Creative Commons by Attribution Licence. Use, distribution and reproduction are unrestricted. Authors and original publication must be credited. 
actions that are simply additive, or (3) more complex interactions (e.g. antagonistic, infra-additive, or supra-additive). In the case of complex interactions, one factor can amplify or interfere with the effect of another factor. For example, nitrogen source (ammonia vs. nitrate) and $p \mathrm{CO}_{2}$ have been shown to synergistically affect carbon allocation and growth of the coccolithophore Emiliania huxleyi (Lefebvre et al. 2012). Growth rates and the toxicity of the diatom Pseudo-nitzschia spp. respond interactively to phosphorus limitation and elevated $p \mathrm{CO}_{2}$ (Sun et al. 2011). The impacts of trace metal availability on phytoplankton growth provide good examples of complex interactions between different environmental stressors (e.g. Sunda \& Huntsman 1997, 2004, Timmermans et al. 2004).

Responses of phytoplankton to changes in temperature, irradiance, nutrient availability, and $p \mathrm{CO}_{2}$ all impact physiological processes associated with carbon acquisition, fixation, and growth. The responses of phytoplankton to the anticipated simultaneous environmental stressors associated with climate change are thus unlikely to be simply additive. For example, Feng et al. (2009) tested the effects of increasing $p \mathrm{CO}_{2}$ and temperature on the composition of a natural phytoplankton community; increasing the temperature by $4^{\circ} \mathrm{C}$ or the $\mathrm{pCO}_{2}$ by $300 \mathrm{ppm}$ produced dramatic changes in the composition of the phytoplankton community, with diatoms favored by increased $p \mathrm{CO}_{2}$ and chrysophytes by increased temperature. The most dramatic result, however, was the coccolithophore bloom produced by increasing both temperature and $p \mathrm{CO}_{2}$ in combination.

Abiotic growth conditions determine not only growth rate and photosynthesis, but also cellular characteristics and excretion rates. Cell quotas and stoichiometry may vary widely as a function of light, temperature, and nutrient availabilities; for example, cellular POC content, even within the same strain of Thalassiosira weissflogii (CCP 1336), may differ by a factor of 3 or more (between 80-228 pg C cell-1) depending on growth conditions (Ho et al. 2003, Price 2005, Finkel et al. 2006, Liu et al. 2011). The abiotic production of transparent exopolymer particles (TEP) from dissolved precursors released by diatoms (Passow 2000) likewise varies as a function of nutrients, light, or temperature (Corzo et al. 2000, Engel et al. 2004, Piontek et al. 2009, Fukao et al. 2012, Seebah et al. 2014, Taucher et al. 2015).

A basic understanding of the general relationships between environmental conditions and growth or cell characteristics is required as input for realistic, predictive models that assess future changes to marine food webs and global elemental cycles. For example, in situ fluorescence determined remotely by satellite, moored instruments, or gliders provides adequate spatial or temporal coverage for global-scale models but needs to be converted to carbon units. It is unclear, however, whether the fluorescence to chlorophyll $a$ $(\mathrm{chl} \mathrm{a}$ ) or the carbon $(\mathrm{C})$ to $\mathrm{chl}$ a ratios will systematically shift in the warmer, more acidic ocean of the future. The elemental ratios of marine phytoplankton regulate the nutrient composition of the deep sea, but questions remain as to whether the globally constant average ratio between carbon and nitrogen during formation and degradation of organic matter, the Redfield ratio (Redfield et al. 1963), will shift in a changing ocean. Shifts in the average elemental ratios away from the Redfield ratio would severely alter carbon sequestration by the ocean (Riebesell et al. 2007, Passow \& Carlson 2012). Thus, it is necessary to identify trends in phytoplankton growth response and elemental cycling to multiple environmental changes.

Early experiments testing the effects of elevated $p \mathrm{CO}_{2}$ on phytoplankton growth frequently appeared to produce opposing results, suggesting interactive effects between different growth conditions. Our goal was to investigate the existence of interactive effects between $p \mathrm{CO}_{2}$ and temperature and irradiance, and to emphasize the importance of suboptimal growth conditions when evaluating the consequences of ocean acidification. Here, we present a study designed to investigate the effect of $p \mathrm{CO}_{2}$ perturbation on growth rates and cell quotas of the marine diatom T. weissflogii grown under suboptimal temperature and irradiance conditions. T. weissflogii is believed to be a cosmopolitan, bloom-forming diatom common in coastal and estuarine waters, although its ubiquitous distribution in blooms has been challenged (Chappell et al. 2013). T. weissflogii grows successfully in culture, and has been used extensively in a wide variety of controlled laboratory experiments (e.g. Bannister \& Laws 1980, Costello \& Chisholm 1981, Murphy \& Cowles 1997, Vrieling et al. 1999, Ishida et al. 2000, Strzepek \& Price 2000, Montagnes \& Franklin 2001, Parker et al. 2004, Laney et al. 2005, Roberts et al. 2007, Halac et al. 2010, Katayama et al. 2012). Primarily, these studies investigated the response of $T$. weissflogii to one environmental stressor under otherwise optimal growth conditions. We used this wellstudied species to test the null hypothesis that elevated $p \mathrm{CO}_{2}$ had no significant effect on its growth rate or cell quota of POC, PON, and chl a (Burkhardt et al. 1999, Reinfelder 2012), even in the presence of suboptimal growth conditions including light and temperature stress. 


\section{MATERIALS AND METHODS}

\section{Set-up of multiple-stressor experiments}

The interactive effects of temperature light, and $p \mathrm{CO}_{2}$ on elemental composition and growth of the diatom Thalassiosira weissflogii were explored in 9 experiments. The strain CCMP 1053 of Thalassiosira weissflogii (Grunnow) Fryxell \& Hasle 1977, sometimes referred to by its taxonomic synonym Thalassiosira fluviatilis (Hustedt, 1926), of the Class Coscinodiscophycea was used in our study. This strain belongs to the Atlantic-Californian Cluster, one of 3 distinct sub-species or species of the T. weissflogii group (Sorhannus et al. 2010). Cells were grown at 5 temperatures $\left(5,10,15,20\right.$, and $\left.25^{\circ} \mathrm{C}\right)$ to cover the growth temperature range and under low light (LL; $35 \mu \mathrm{mol}$ photons $\mathrm{m}^{-2} \mathrm{~s}^{-1}$ ) and ambient $p \mathrm{CO}_{2}(\mathrm{Amb})$ conditions. The LL irradiance was selected to provide sub-saturating light conditions (stressor) that allow measurable growth; the saturating irradiance level is $\geq 135 \mu \mathrm{mol}$ photons $\mathrm{m}^{-2} \mathrm{~s}^{-1}$ (Strzepek \& Price 2000, Parker et al. 2004, Finkel et al. 2006). Additionally, cells were grown at $15^{\circ} \mathrm{C}$ and $20^{\circ} \mathrm{C}$ under LL and future $\mathrm{pCO}_{2}$ (Fut) conditions, as well as at $20^{\circ} \mathrm{C}$ under higher, but sub-saturating light levels (HL; $65 \mu \mathrm{mol}$ photons $\mathrm{m}^{-2} \mathrm{~s}^{-1}$ ) at both ambient and future $p \mathrm{CO}_{2}$ conditions. Experimental conditions are designated using these acronyms for temperature, light, and $p \mathrm{CO}_{2}$. For example, ' $15^{\circ} \mathrm{C} \mathrm{LL} \mathrm{Amb}$ identifies the experiment where cells were grown at $15^{\circ} \mathrm{C}, 35 \mu \mathrm{mol}$ photons $\mathrm{m}^{-2} \mathrm{~s}^{-1}$, and ambient $p \mathrm{CO}_{2}$.

Coastal diatoms such as $T$. weissflogii thrive in environments that fluctuate on timescales of hours to days with variability in nutrient availability and the carbonate system resulting from physical processes including upwelling and mixing, and from biological activities (photosynthesis and respiration) that consume or generate nutrients and $\mathrm{CO}_{2}$. Bloom-forming species like T. weissflogii thus change their own environment significantly when they are growing vigorously. Semi-continuous culturing may mimic such fluctuations while keeping growth conditions within natural environmental ranges. Cultures were thus grown semi-continuously in constant-temperature, walk-in incubators, with cell concentrations and $\mathrm{pH}$ increasing and nutrients and dissolved inorganic carbon (DIC) decreasing between dilutions. The carbonate system, cell concentrations, and nutrient concentrations were kept within specific ranges, with dilutions re-setting these to initial target values. Dilutions were initiated when final target values were reached for at least one of the parameters; thus, dilu- tion frequency was a function of growth and not constant. In Amb treatments, the $\mathrm{pH}$ fluctuations were targeted to remain between 8.0 and 8.6, whereas in Fut treatments, the target was between 7.5 and 8.3 , mimicking development of a bloom under either preindustrial and future, or under non-upwelling and upwelling conditions. All cultures were grown in Fernbach flasks (1 l) on a $14 \mathrm{~h}$ light:10 h dark cycle. Preliminary experiments and theoretical considerations confirmed that changes in the carbonate system due to exchange with the stagnant airspace above the cultures were negligible relative to changes due to photosynthesis and respiration. Due to logistical constraints, the experiments were conducted in series using the same stock culture and media throughout. Each experiment consisted of 4 replicates, except for the $2 \mathrm{HL}$ experiments, which were conducted in triplicate. Each experiment was divided into an acclimatization phase and a measurement phase.

Seawater based media were prepared directly before use with all the seawater collected off Santa Barbara, California, before the onset of experiments. Initially, about 2501 of seawater $(S=33.0)$ were mixed, filtered through a $0.2 \mu \mathrm{m}$ cartridge filter (Sartobrand), and stored in cool and dark conditions until media preparation. When preparing media, the seawater was again filtered through a $0.2 \mu \mathrm{m}$ cartridge filter followed by a $0.2 \mu \mathrm{m}$ Stericap (Millipore) filter, and vitamins and trace metals were added as in f/2 (Guillard 1975). Reduced concentrations of nitrate $\left(\mathrm{NO}_{3} ; 58.9 \mu \mathrm{M}\right)$, phosphate $\left(\mathrm{PO}_{4} ; 3.6 \mu \mathrm{M}\right)$, and silicic acid $\left(\mathrm{Si}[\mathrm{OH}]_{4} ; 53.5 \mu \mathrm{M}\right)$ were added using a $0.2 \mu \mathrm{m}$ syringe filter. Since the seawater contained nutrients, the initial concentrations in the media were slightly higher for $\mathrm{NO}_{3}(72 \pm 5 \mu \mathrm{M}), \mathrm{PO}_{4}(3.8 \pm 0.5 \mu \mathrm{M})$, and $\mathrm{Si}(\mathrm{OH})_{4}(54 \pm 4 \mu \mathrm{M})$. The carbonate chemistry was adjusted as necessary by adding $\mathrm{HCl}, \mathrm{NaHCO}_{3}$, and $\mathrm{Na}_{2} \mathrm{CO}_{3}$ (closed system approach) as described in Passow (2012). Chemically, the carbonate system perturbation using the closed system approach is identical to that conducted via bubbling (Rost et al. 2008), with the added advantage that the production of particles from DOM due to bubbling is avoided (Kepkay \& Johnson 1989, Mopper et al. 1995). The light climate was carefully adjusted for each replicate, and light and temperature were checked throughout the experimental period for consistency. Cultures were not continuously aerated, bubbled, or shaken, but mixed gently daily and before sampling.

Each Fernbach flask was inoculated from the same stock culture, which was grown at $15^{\circ} \mathrm{C}$ under $35 \mu \mathrm{mol}$ photons $\mathrm{m}^{-2} \mathrm{~s}^{-1}$ light on a $12 \mathrm{~h}$ light:12 h dark 
cycle. Cultures were diluted with fresh media adjusted to the appropriate temperature and $\mathrm{pH}$ whenever cell concentrations approached 40000 to 50000 cells ml$^{-1}$, or the $\mathrm{pH}$ approached 8.6 (Amb) or 8.3 (Fut). This cell concentration had previously been established to allow continued exponential growth at these nutrient additions. Dilution reduced cell concentrations to no less than 10000 cells ml ${ }^{-1}$ by replacing excess culture with media that was adjusted to yield the correct $\mathrm{pH}$ and alkalinity at in vitro temperature. All 4 replicates were diluted on the same day, and all culture work was conducted on a clean bench. Depending on the growth rate, cell concentration (replicate no. 1 only), dark-adapted fluorescence $\left(F_{0}\right)$, photosystem II efficiency $\left(F_{\mathrm{v}} / F_{\mathrm{m}}\right)$, and $\mathrm{pH}$ were determined in all 4 replicates every $1-3 \mathrm{~d}$ in the morning, $2-3 \mathrm{~h}$ after the start of the light cycle. Cell concentration (replicate no. 1 ) and $F_{0}$ (all replicates) were additionally determined on dilution days just before and directly after dilution. Total alkalinity (TA) and, frequently, dissolved inorganic carbon (DIC) were also measured on dilution days. Nutrient concentrations were measured before every dilution in 2 experiments and on an irregular basis in the others.

Cell numbers in replicate nos. 2-4 were calculated from the respective $F_{0}$ measurements by using the relationship between $F_{0}$ and cell numbers derived from replicate no. 1 of that experiment. The fluorescence-to-cell-number relationship was highly consistent within each experiment, but varied between experiments. Exponential growth rates between dilutions were determined by fitting an exponential curve to cell concentrations. A comparison of average growth rates based on the light period (early morning to afternoon) with those based on the dark period (afternoon to early morning) confirmed that the majority of cell divisions took place during the dark period. The acclimatization phase was terminated after the exponential growth rate $(\mu)$ was constant $\left( \pm 0.03 \mathrm{~d}^{-1}\right)$ for at least 8 generations. Average cell size was determined manually under the microscope from 20 random cells per sample in experiments, where a change in cell size was obvious.

The subsequent measuring phase consisted of 4 measurement days, with sampling either daily or every second day, depending on the growth rate. Cell concentrations, the carbonate system, and additionally chlorophyll a (chl a), dry weight (DW), particulate organic carbon and nitrogen (POC and PON), and transparent exopolymer particles (TEP) were determined on the 4 measuring days in all 4 replicates.

\section{The carbonate system}

The carbonate system was adjusted using the closed system approach (Passow 2012). Briefly, the carbonate system of the collected seawater $\left(\mathrm{TA}_{\text {media }}=\right.$ $2370 \mu \mathrm{mol} \mathrm{kg}{ }^{-1}, \mathrm{pH}_{\text {Tmedia }}=7.99$ ) was altered chemically by adding appropriate amounts of $\mathrm{HCl}$, $\mathrm{NaHCO}_{3}$, and $\mathrm{Na}_{2} \mathrm{CO}_{3}$. This type of perturbation leads to a carbonate chemistry identical to the chemistry produced by bubbling with $p \mathrm{CO}_{2}$ enriched gas, but avoids artifacts like TEP formation that are caused by bubbling (Passow 2012, Seebah et al. 2014, Taucher et al. 2015). At the beginning of each experiment, one batch of medium was prepared and divided between the 4 replicates. Media used for each dilution were adjusted individually for each replicate directly before dilution by adjusting the carbonate system of the medium to the value required to reach the target $\mathrm{pH}$ without changing the TA. Because the silicic acid solution of $f / 2$ is very basic, a correction for nutrient addition was required to reach target $\mathrm{pH}$ accurately. Calculations were regularly confirmed by measurements.

Any parameter of the carbonate system may be calculated unambiguously from any 2 carbonate system parameters using the program CO2Sys (Lewis \& Wallace 1998). The dissociation constants K1 and K2, refit according to Dickson \& Millero (1987) and $\mathrm{KHSO}_{4}$ according to Dickson et al. (2007), were used for calculations. The carbonate system was monitored by measuring $\mathrm{pH}$ on the total scale $\left(\mathrm{pH}_{\mathrm{T}}\right), \mathrm{TA}$ (on dilution days), and DIC (occasionally in parallel to TA). Samples were collected, prepared, and processed following 'Guides to Best Practices for Ocean $\mathrm{CO}_{2}$ Measurements' (Dickson et al. 2007, Riebesell et al. 2010). Samples for $\mathrm{pH}$ were collected bubble-free in $20 \mathrm{ml}$ scintillation vials and analyzed within $1-2 \mathrm{~h}$ after collection. Samples for TA were filtered $(0.6 \mu \mathrm{m}$ filter), stored in $150 \mathrm{ml}$ borosilicate bottles, and fixed with $\mathrm{HgCl}_{2}$. DIC samples were filtered through $0.2 \mu \mathrm{m}$ cellulose-acetate filters, dispensed into $5 \mathrm{ml}$ borosilicate bottles, and also fixed with saturated $\mathrm{HgCl}_{2}$ (final concentration $=0.19 \mathrm{vol} \%$ ). Both were stored in cool and dark conditions until analysis at the Alfred Wegener Institute in Bremerhaven, Germany.

The total scale $\mathrm{pH}\left(\mathrm{pH}_{\mathrm{T}}\right)$ was measured with a spectrophotometer (Genesys 10SVIS) equipped with a single cell Peltier SPG1A (Thermo Scientific) using the indicator dye m-cresol purple (Sigma Aldrich) at a constant temperature of $25^{\circ} \mathrm{C}$. The absorbance was measured at $730 \mathrm{~nm}, 578 \mathrm{~nm}$, and $434 \mathrm{~nm}$ before and after dye addition (Clayton \& Byrne 1993, Fangue et 
al. 2010). The $\mathrm{pH}_{\mathrm{T}}$ was calculated following SOP6b. The TA was calculated from linear Gran plots (Gran 1952) after duplicate potentiometric titrations (Brewer et al. 1986) using a TitroLine alpha plus (Schott Instruments); average precision was $\pm 5 \mu \mathrm{mol}$ $\mathrm{kg}^{-1}$. A Certified Reference Materials (CRM), Batch No. 54, standard supplied by A. Dickson (Scripps Institution of Oceanography, USA) was used as a control. DIC was measured colorimetrically in duplicate with a TRAACS CS800 AutoAnalyzer (Seal) with a precision of $\pm 5 \mu \mathrm{mol} \mathrm{kg}^{-1}$. A CRM (Batch No. 54) supplied by A. Dickson was used for calibration purposes (for detailed methods, see Hoppe et al. 2012). Averages of replicate measurements of TA and DIC were used, and all parameters are presented for the respective experimental (in vitro) temperatures.

\section{Nutrients and light}

Concentrations of $\mathrm{NO}_{3}+\mathrm{NO}_{2}, \mathrm{PO}_{4}$, and $\mathrm{Si}(\mathrm{OH})_{4}$ were measured by simultaneous flow injection analysis on a QuickChem 8000 (Lachat Instruments) from pre-filtered frozen samples. Photon flux density was measured in air with a newly calibrated, flat light sensor (LICOR) positioned at the center of the circles in which the replicate flasks were placed.

\section{Cell concentration, health, and growth rates}

Cells were counted microscopically (Olympus CX41) with a hemocytometer; at least 10 subsamples or 200 cells per sample were counted. Dark-adapted instantaneous minimum chlorophyll fluorescence $\left(F_{0}\right)$ and dark adapted $F_{\mathrm{v}} / F_{\mathrm{m}}$, which is a measure of photosystem II efficiency, were recorded with a portable fluorometer, the Z985 Cuvette Aquapen (Qubit Systems). The blue (455 nm) light emitting diode was used for detection of fluorescence of $3 \mathrm{ml}$ samples in $1 \mathrm{~cm}$ cuvettes. Dark adaptation time for $F_{0}$ and $F_{\mathrm{v}} / F_{\mathrm{m}}$, for this species had initially been determined by measuring $F_{0}$ in 10 replicates after 5-25 min at 2-min intervals in the dark and cold. After 5 min, darkadapted $F_{0}$ remained constant, and this dark-adaptation period was used for all measurements. The relationship between cell number and $F_{0}$ in replicate no. 1 was used to calculate cell numbers for the other replicates of that experiment. Exponential growth rates $(\mu)$ were then calculated by fitting cell numbers $(C)$ over time $(t)$ to an exponential curve: $\ln \left(C_{2} / C_{1}\right) /$ $\left(t_{2}-t_{1}\right)$, where 1 and 2 denote two different time points. The generation time was calculated as $\mathrm{T}_{\mathrm{d}}=$ $1 /(\mu / \ln 2)$. Since the average $F_{0}$ :cell ratio was well correlated with the respective chl a: cell ratio $\left(F_{0}\right.$ :cell = $0.63 \times \mathrm{chl}$ a:cell $\left.+2.12 ; r^{2}=0.94\right), F_{0}$ will not be discussed separately. $F_{\mathrm{v}} / F_{\mathrm{m}}$ decreases at the onset of $\mathrm{N}$-stress, or when growth conditions begin to deteriorate. In preliminary tests, the $F_{\mathrm{v}} / F_{\mathrm{m}}$ value of $T$. weissflogii dropped below 0.5 about 1 day before a decrease in growth rate became apparent. $F_{v} / F_{\mathrm{m}}$ was thus used as a convenient proxy for nutrient availability.

\section{Biomass, transparent exopolymer particles (TEP), and photosynthesis}

Dry weight, particulate organic carbon (POC), and particulate organic nitrogen $\mathrm{PON}$ were all measured on the same filter, in duplicate. Samples (50-100 ml) were filtered onto pre-weighed GF/F filters, dried at $60^{\circ} \mathrm{C}$, and reweighed. Filters were then analyzed for POC and PON using an elemental analyzer (CEC $44 \mathrm{OHA}_{i}$ Control Equipment). Duplicate samples were filtered onto $0.4 \mu \mathrm{m}$ PC filters, which were soaked in $90 \%$ acetone overnight in the freezer before chl a was measured on a fluorometer (Turner 700) according to Strickland (1972). TEP, expressed as Gum Xanthan equivalents per liter (GXeq $1^{-1}$ ), was measured colorimetrically in 4 replicates per sample by filtration of $15-100 \mathrm{ml}$ onto $0.4 \mu \mathrm{m}$ PC filters (Poretics) and subsequent staining with Alcian Blue (Passow \& Alldredge 1995). Determination of TEP is semi-quantitative because the chemical composition of TEP varies and is unknown. TEP-carbon was estimated from TEP concentrations for the calculations of estimated photosynthesis using the average conversion factor of $0.75 \pm 0.05 \mu \mathrm{g} \mathrm{C} \mu \mathrm{g} \mathrm{GXeq}^{-1}$ (Engel \& Passow 2001). Trends and relationships were not affected when TEP carbon was calculated using a conversion factor of $0.51 \pm 0.06 \mu \mathrm{g} \mathrm{C} \mu \mathrm{g} \mathrm{GXeq}^{-1}$, specific for an unknown strain of T. weissflogii. Estimated cellular photosynthesis was determined from growth rate and cell-normalized POC and TEPcarbon concentrations, thus including the production of both cellular and extracellular organic carbon.

\section{Determination of the relationships between growth rate, and temperature and irradiance}

The relationship between growth rates and irradiance at a fixed temperature was assumed to be described by a negative exponential function of the 
form: $\mu=\mu_{\mathrm{m}}\left(1-\mathrm{e}^{-I / K_{I}}\right)$, where $\mu_{\mathrm{m}}$ is the light-saturated growth rate, and the slope of the function as $I \rightarrow 0$ equals $\mu_{\mathrm{m}} / K_{I}$ (Laws et al. 2002). The parameter $K_{I}$ is equal to the irradiance at which the growth rate is $63 \%$ of $\mu_{\mathrm{m}}$. The parameters $\mu_{\mathrm{m}}$ and $K_{I}$ were determined by least squares fits of the experimental growth rates and irradiances. In the case of the growth rates at $20^{\circ} \mathrm{C}$, we compared our results with the data reported by Laws \& Bannister (1980). The parameter $K_{I}$ was assumed to be temperature dependent (Caperon 1967), and we assumed the dependence to be described by an exponential function. The 2 parameters in the exponential function were determined from the $K_{I}$ values that characterized the $\mu$ versus $I$ curves at 15 and $20^{\circ} \mathrm{C}$. The growth rate data at $I=35 \mu \mathrm{mol}$ photons $\mathrm{m}^{-2} \mathrm{~s}^{-1}$ were compared with the data reported by Montagnes \& Franklin (2001). The relationship between $\mu$ and temperature at that irradiance was characterized by a polynomial function of temperature with 3 coefficients determined by least squares. All of the polynomial coefficients were significant at $\mathrm{p}<0.05$.

\section{Statistical analysis}

During the measurement phase, variability observed between replicate culture flasks was compared to that between sequential sampling times within one flask. Coefficients of variation $\left(\mathrm{CV}_{i}\right.$ calculated as $\mathrm{SD} / \mathrm{mean})$ were calculated for each approach, and compared using a $t$-test with a correction for repeated use. Since no statistical difference between the CV of both sampling strategies was found, data from the replicate flasks were combined with that of the time series measurements and values reported as mean \pm SE of replicates $(n=16$ and 12 for LL and HL treatments, respectively).

ANOVA using least-squares fit (Excel 2010), was used to test the respective null hypothesis that cultures in the different experiments did not differ statistically from each other. A follow-up t-test was used to test the null hypothesis that growth rates of specific pairs of experiments did not differ statistically. A one-way ANOVA was used to test whether cell characteristics differed as a function of temperature, and two-way ANOVAs with replications were used to test the hypothesis that the specific cell characteristics and TEP production were not influenced by $p \mathrm{CO}_{2}$ and temperature, or by $p \mathrm{CO}_{2}$ and light. ANOVAs treat replicates as independent results. Assumption of dependence between the time series points requires a multivariate repeat measure analysis (repeat measure MANOVA), which was conducted using JMP 10. Those results did not differ appreciably from those assuming independence (data not shown), confirming the results from our variability analysis. The null hypothesis that growth and other response variables did not differ between experimental treatments was tested with a conservative alpha of 0.001 . General results did not differ if an alpha of 0.05 was used.

\section{RESULTS}

\section{Growth conditions}

Temperature, irradiance, and photoperiod were constant and as targeted in all experiments. Trace nutrients were added in excess to ensure that changes in their bioavailability due to changed carbonate chemistry would have no effect. Macronutrient concentrations fluctuated between high values directly after dilution and low values directly before dilution. Silicic acid concentrations were always above $12 \mu \mathrm{M}$. During the acclimatization phase, phosphate and nitrate + nitrite concentrations occasionally reached their respective detection limits immediately before dilution $\left(\mathrm{PO}_{4}=0.1 \mu \mathrm{M}\right.$ and $\left.\mathrm{NO}_{3}+\mathrm{NO}_{2}=0.2 \mu \mathrm{M}\right)$, however, judging from the continued exponential growth and consistently high $F_{\mathrm{v}} / F_{\mathrm{m}}$ values, periods with these conditions were brief enough to not affect growth.

In 109 of our samples, we measured 3 carbonate parameters, $\mathrm{pH}, \mathrm{TA}$, and DIC, effectively over-determining the carbonate system; the inconsistencies between $p \mathrm{CO}_{2}$ concentrations calculated from the over-determined dataset (data not shown) were consistent with those described previously (Hoppe et al. 2012, Passow 2012, Seebah et al. 2014). The $p \mathrm{CO}_{2}$ as calculated from TA and DIC was 20-30\% lower than that calculated from $\mathrm{pH}$ and either TA or DIC (Hoppe et al. 2012). Reported values are based on $\mathrm{pH}$ and TA or DIC as recommended.

TA concentrations fluctuated mildly during the experiments (decreasing by 20-50 $\mu \mathrm{mol} \mathrm{kg}^{-1}$ between dilutions) as nutrients were being utilized, but overall TA remained fairly constant with an average of $2384 \pm 45$ (SD) $\mu \mathrm{mol} \mathrm{kg} \mathrm{kg}^{-1}$ (n = 252) for all experiments and replicates. Between dilutions, DIC decreased and $\mathrm{pH}_{\mathrm{T}}$ increased accordingly, with values of Amb and Fut treatments overlapping, but with different averages and extremes between $p \mathrm{CO}_{2}$ treatments (Table 1). The target maximal $\mathrm{pH}_{\mathrm{T}}$ range was set for $0.6 \mathrm{pH}$ units (8.0-8.6) in Amb, but for 
Table 1. Experimental conditions and minimum and maximum total-scale $\mathrm{pH}\left(\mathrm{pH}_{\mathrm{T}}\right)$ during acclimatization phases of the experimental treatments

\begin{tabular}{|lccc|}
\hline $\begin{array}{l}\text { Temp. } \\
\left({ }^{\circ} \mathrm{C}\right)\end{array}$ & $\begin{array}{c}\text { Irradiance } \\
\left(\mu \mathrm{mol} \mathrm{s}^{-1} \mathrm{~m}^{2}\right)\end{array}$ & Ambient & $\mathrm{pH}_{\mathrm{T}}$ \\
\hline 10 & 35 & $7.98-8.36$ & Future \\
15 & 35 & $8.02-8.93$ & $7.67-8.11$ \\
20 & 35 & $8.05-8.59$ & $7.49-8.29$ \\
20 & 65 & $8.03-8.26$ & $7.62-8.45$ \\
\hline
\end{tabular}

0.8 units ( 7.5 to 8.3 ) in Fut treatments because the marine carbonate buffer system weakens under ocean acidification, and $\mathrm{pH}$ responses to growth are thus higher. The changes in $\mathrm{pH}_{\mathrm{T}}$ (Table 1) reflected the uptake of DIC and were a very sensitive indicator of carbon assimilation, with the exception of the $25^{\circ} \mathrm{C}$ experiment. At $25^{\circ} \mathrm{C}$, the $\mathrm{pH}_{\mathrm{T}}$ represented $\mathrm{Amb}$ conditions as expected until day 25, when the $\mathrm{pH}$ dropped to a value that averaged $7.76 \pm 0.02$ during the 2 days following the dilution. This drop in $\mathrm{pH}$ was observed in all 4 replicates and indicates that respiration dominated over photosynthesis. The experiment was terminated, and growth at $25^{\circ} \mathrm{C}$ re-initiated twice with 4 replicates each. Cells did not grow, suggesting that this temperature-irradiance combination was unsuitable for growth of $T$. weissflogii. Cells did not grow in any of the replicates at $5^{\circ} \mathrm{C}$. The $\mathrm{pH}_{\mathrm{T}}$ in experiments at $10^{\circ} \mathrm{C}, 15^{\circ} \mathrm{C}$, and $20^{\circ} \mathrm{C}$ remained within the target ranges, except in $15^{\circ} \mathrm{C}$ LL Amb treatment, which briefly exceeded the target range twice (reaching a $\mathrm{pH}_{\mathrm{T}}$ of 8.9 ), and $20^{\circ} \mathrm{C}$ HL Fut, which briefly exceeded 8.3 once (Table 1). These changes in $\mathrm{pH}$ during growth at this TA are equivalent to a decrease in the $p \mathrm{CO}_{2}$ from $\sim 1650$ to $\sim 200$ in Fut and from $\sim 460$ to $\sim 80$ in Amb treatments, with small differences in the upper and lower limits depending on temperature.

Cell concentrations fluctuated within the targeted range, and after 1-3 wk of exponential cell growth the $F_{\mathrm{v}} / F_{\mathrm{m}}$ values were always $\geq 0.6$, signifying that cells were not exposed to new or unforeseen stressors. During the acclimatization phase, which lasted 2-6 wk, exponential growth rate increased on a timescale of weeks in some experiments. For example, at $10^{\circ} \mathrm{C}$ LL Amb, exponential growth was $0.16 \mathrm{~d}^{-1}$ after $7 \mathrm{~d}$, but remained at $0.35 \pm 0.02 \mathrm{~d}^{-1}$, which was reached after $28 \mathrm{~d}$, for more than 8 generations. Similarly, the cells at $15^{\circ} \mathrm{C}$ LL Amb grew at $0.23 \mathrm{~d}^{-1}$ between Days 7 and 12, and after $20 \mathrm{~d}$ reached $0.69 \pm$ $0.00 \mathrm{~d}^{-1}$, and this growth rate remained constant for $\geq 8$ generations.

\section{Growth as a function of temperature, light, and $\mathrm{pCO}_{2}$}

Examination of our results and the results of Seebah et al. (2014) and Taucher et al. (2015) revealed that the relationship between acclimatized growth rates and irradiance under ambient $p \mathrm{CO}_{2}$ conditions was very different at 15 and $20^{\circ} \mathrm{C}$ (Fig. $1 \mathrm{a}$, Tables 2 $\& 3)$. The analytical functions fitted to the experimental data indicated that both $\mu_{\mathrm{m}}$ and $K_{I}$ were higher at
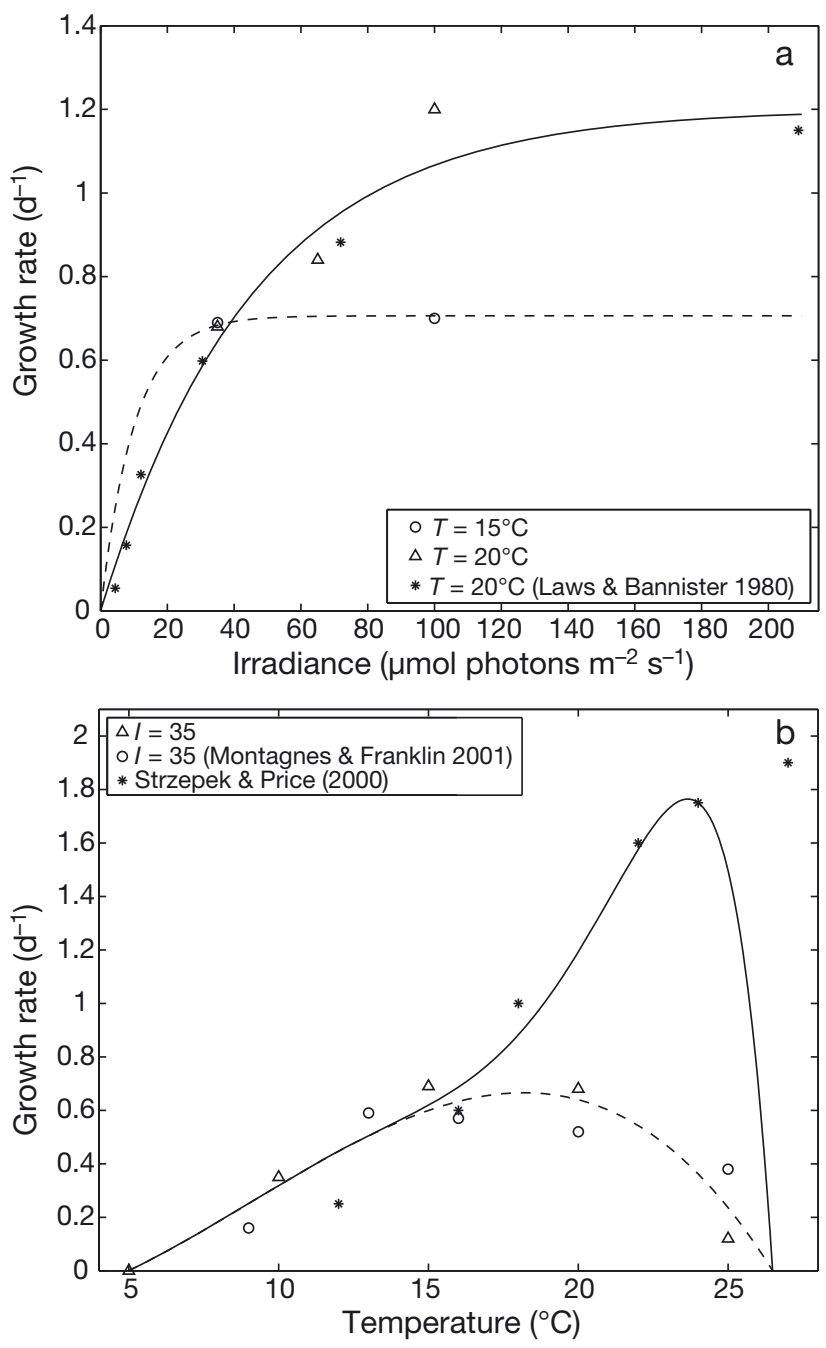

Fig. 1. Growth rates vs. irradiance $(I)$ and temperature $(T)$ based on experimental data presented in this study, with 1 data point $\left(20^{\circ} \mathrm{C}\right.$ at $100 \mu \mathrm{mol}$ photons $\left.\mathrm{m}^{-2} \mathrm{~s}^{-1}\right)$ from Taucher et al. (2015). (a) Growth rates vs. irradiance, where negative exponential functions were fit to all data at $20^{\circ} \mathrm{C}$ (solid line) and at $15^{\circ} \mathrm{C}$ (dashed line). (b) Growth rates vs. temperature, where a polynomial with 3 coefficients was fitted to all data at $I=35 \mu \mathrm{mol}$ photons $\mathrm{m}^{-2} \mathrm{~s}^{-1}$ (dashed line), and the value of $\mu_{\mathrm{m}}$ (solid line) was determined from the polynomial and the exponential temperature dependence of $K_{I}$ 
Table 2. Mean \pm SE of growth rates, photosynthetic rates, cellular characteristics, cell quotas $(D W=$ dry weight, $\mathrm{POC}=$ particulate organic carbon, $\mathrm{PON}$ = particulate organic nitrogen) and transparent exopolymer particle (TEP) concentrations during the measuring phase of the different experiments. Experimental treatments included temperature $\left(10,15\right.$, and $\left.20^{\circ} \mathrm{C}\right)$, irradiance $\left(\mathrm{LL}=\right.$ low light, $\mathrm{HL}=$ high light levels), and $\mathrm{CO}_{2}$ partial pressure $\left(\mathrm{Amb}=\right.$ ambient $p \mathrm{CO}_{2}$, Fut $=$ future $\left.p \mathrm{CO}_{2}\right)$. Growth rates of Thalassiosira weissflogii from identical stock (grown at an irradiance of $100 \mu \mathrm{mol} \mathrm{m}^{-1} \mathrm{~s}^{-1}$ at $15^{\circ} \mathrm{C}$ and $20^{\circ} \mathrm{C}$ ) were $0.7 \pm 0.1 \mathrm{~d}^{-1}$ and $1.2 \pm 0.1 \mathrm{~d}^{-1}$, respectively (Taucher et al. 2015)

\begin{tabular}{|c|c|c|c|c|c|c|c|}
\hline & $\begin{array}{c}10^{\circ} \mathrm{C} \\
\mathrm{LL} \\
\mathrm{Amb}\end{array}$ & $\begin{array}{c}15^{\circ} \mathrm{C} \\
\mathrm{LL} \\
\mathrm{Amb}\end{array}$ & $\begin{array}{c}15^{\circ} \mathrm{C} \\
\mathrm{LL} \\
\text { Fut }\end{array}$ & $\begin{array}{c}20^{\circ} \mathrm{C} \\
\mathrm{LL} \\
\mathrm{Amb}\end{array}$ & $\begin{array}{c}20^{\circ} \mathrm{C} \\
\text { LL } \\
\text { Fut }\end{array}$ & $\begin{array}{c}20^{\circ} \mathrm{C} \\
\mathrm{HL} \\
\mathrm{Amb}\end{array}$ & $\begin{array}{c}20^{\circ} \mathrm{C} \\
\mathrm{HL} \\
\text { Fut }\end{array}$ \\
\hline Growth rate $\left(\mathrm{d}^{-1}\right)$ & $0.35 \pm 0.01$ & $0.69 \pm 0.00$ & $0.19 \pm 0.01$ & $0.68 \pm 0.02$ & $0.62 \pm 0.01$ & $0.84 \pm 0.02$ & $0.75 \pm 0.04$ \\
\hline $\begin{array}{l}\text { Estimated cellular photo- } \\
\text { synthesis (pg C cell }{ }^{-1} \mathrm{~d}^{-1} \text { ) }\end{array}$ & $96 \pm 4$ & $99 \pm 2$ & $63 \pm 5$ & $80 \pm 3$ & $65 \pm 2$ & $182 \pm 12$ & $184 \pm 12$ \\
\hline C:N (weight) & $7.2 \pm 0.1$ & $7.2 \pm 0.1$ & $5.6 \pm 0.2$ & $6.5 \pm 0.2$ & $6.0 \pm 0.1$ & $4.8 \pm 0.1$ & $5.7 \pm 0.2$ \\
\hline C:chl a $\left(\mathrm{g} \mathrm{g}^{-1}\right)$ & $63 \pm 4$ & $40 \pm 2$ & $17 \pm 2$ & $41 \pm 3$ & $45 \pm 3$ & $26 \pm 2$ & $26 \pm 2$ \\
\hline Chl a (pg cell $\left.{ }^{-1}\right)$ & $3.3 \pm 0.2$ & $2.6 \pm 0.1$ & $13.5 \pm 0.8$ & $2.1 \pm 0.1$ & $1.7 \pm 0.1$ & $6.0 \pm 0.3$ & $7.8 \pm 0.6$ \\
\hline DW (pg cell ${ }^{-1}$ ) & $890 \pm 57$ & $344 \pm 14$ & $1011 \pm 129$ & $375 \pm 20$ & $298 \pm 29$ & $596 \pm 64$ & $786 \pm 80$ \\
\hline POC (pg cell $\left.{ }^{-1}\right)$ & $206 \pm 8$ & $104 \pm 3$ & $225 \pm 18$ & $87 \pm 4$ & $77 \pm 3$ & $154 \pm 10$ & $200 \pm 10$ \\
\hline PON (pg cell ${ }^{-1}$ ) & $28.6 \pm 1.2$ & $14.6 \pm 0.4$ & $40.1 \pm 2.2$ & $13.3 \pm 0.4$ & $12.8 \pm 0.6$ & $32.3 \pm 2.7$ & $35.5 \pm 1.8$ \\
\hline TEP (pg GXeq cell ${ }^{-1}$ ) & $96 \pm 7$ & $56 \pm 2$ & $153 \pm 26$ & $44 \pm 2$ & $40 \pm 1$ & $89 \pm 28$ & $64 \pm 11$ \\
\hline
\end{tabular}

Table 3. Results from ANOVA $(\alpha=0.001)$ testing the null hypothesis that growth and other response variables did not differ between experimental treatments. Response variables are the growth rates, photosynthetic rates, cellular characteristics, cell quotas (DW = dry weight, $\mathrm{POC}=$ particulate organic carbon, $\mathrm{PON}=$ particulate organic nitrogen) and transparent exopolymer particle (TEP) concentrations during the measuring phase of the different experiments. Experimental treatments included temperature $\left(T ; 10,15\right.$, and $\left.20^{\circ} \mathrm{C}\right)$, irradiance $(\mathrm{LL}=$ low light, $\mathrm{HL}=$ high light levels $)$, and $\mathrm{CO}_{2}$ partial pressure $($ Amb $=\mathrm{ambient}$ $p \mathrm{CO}_{2}$, Fut $=$ future $p \mathrm{CO}_{2}$ ) ${ }^{* * *}=\mathrm{p}<0.001$ (null hypothesis rejected), ns = not significantly different. Photosynthesis was calculated from POC quota, cell normalized TEP-carbon content and growth rate

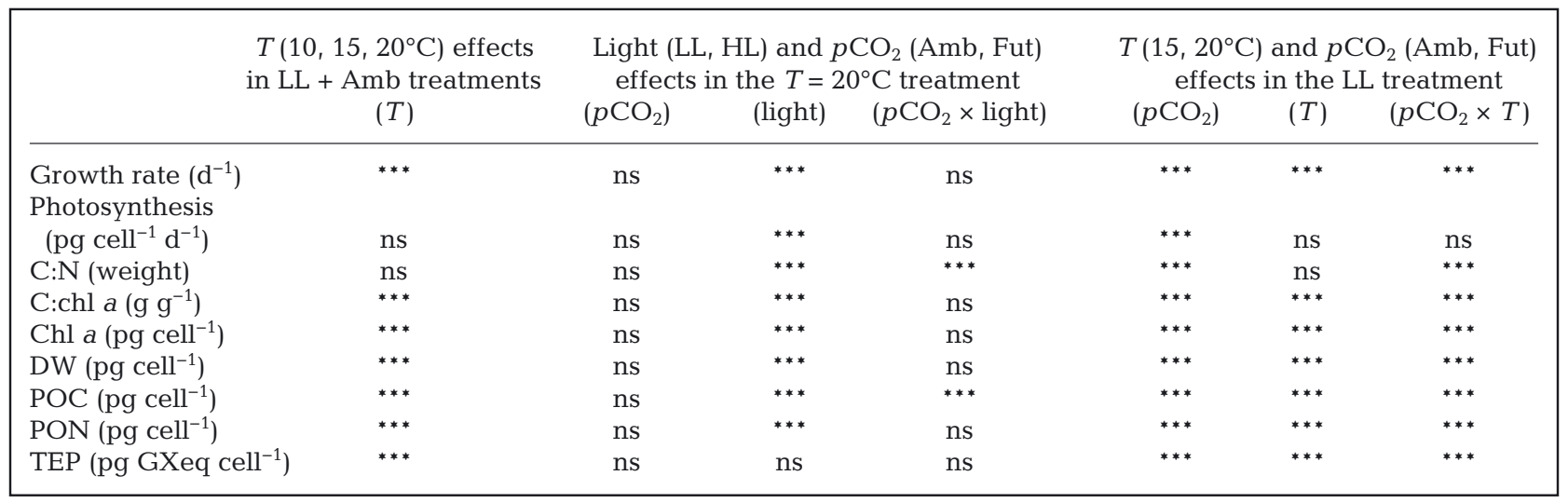

$20^{\circ} \mathrm{C}$ than at $15^{\circ} \mathrm{C}$. Growth rates as a function of temperature $(T)$ at an irradiance of $35 \mu \mathrm{mol}$ photons $\mathrm{m}^{-2}$ $\mathrm{s}^{-1}$ were appropriately described by a 3-term polynomial (constant, $T$, and $T^{4}$ ) that explained $85 \%$ of the variance of the experimental growth rates (Fig. 1b). Combining this polynomial function with the assumed exponential temperature dependence of $K_{I}$ produced a temperature-dependent $\mu_{\mathrm{m}}$ that was in agreement with the light-saturated growth rate data reported by Strzepek \& Price (2000) at temperatures $<25^{\circ} \mathrm{C}$ (Fig. 1b). Strzepek \& Price (2000) used strain CCMP 1336, which, similarly to our strain (CCMP 1053), belongs to the Atlantic-Californian cluster, and is one of 3 biologically distinct species of $T$. weissflogii (Sorhannus et al. 2010). The growth rate vs. temperature-light relationship was also in agreement with data from Laws \& Bannister (1980), who most likely used CCMP 1050 of the Atlantic cluster, and with data from an unknown strain (Montagnes \& Franklin 2001), presumably also belonging to the Atlantic cluster (Fig. 1).

The effect of increased $p \mathrm{CO}_{2}$ on growth rate depended on growth temperature and light (Fig. 2a); elevated $p \mathrm{CO}_{2}$ led to a highly significant $(\mathrm{p}<0.001)$ decrease in growth rate at $15^{\circ} \mathrm{C}$, and to a small, but significant $(p<0.05)$ decrease in growth rate at $20^{\circ} \mathrm{C}$ 
at an irradiance of $35 \mu \mathrm{mol}$ photons $\mathrm{m}^{-2} \mathrm{~s}^{-1}$. At the higher irradiance $\left(20^{\circ} \mathrm{C} \mathrm{HL}\right)$, however, no statistically significant difference in growth rate as a function of $p \mathrm{CO}_{2}$ was observed (Tables $2 \& 3$ ).

Estimated cellular photosynthesis, which was calculated from growth rate and cellular POC plus TEP-carbon, likely represents a conservative estimate because cells presumably released substances other than TEP-precursors. For example, Thalassiosira sp. is known to produce copious quantities of chitan fibrils that readily break off into the medium (McLachlan et al. 1965). Estimated cellular photosynthesis was not impacted by temperature in the acclimatized cultures $\left(10^{\circ} \mathrm{C} \mathrm{LL} \mathrm{Amb}, 15^{\circ} \mathrm{C}\right.$ LL Amb, $\left.20^{\circ} \mathrm{C} \mathrm{LL} \mathrm{Amb}\right)$, but an increase of irradiance $\left(20^{\circ} \mathrm{C}\right.$ HL vs. $20^{\circ} \mathrm{C} \mathrm{LL}$ ) led to a dramatic increase of cellular photosynthesis (Fig. 2b, Tables 2 \& 3). For growth rates, increased $p \mathrm{CO}_{2}$ led to a significant decrease in cellular photosynthesis at $35 \mu \mathrm{mol}$ photons $\mathrm{m}^{-2} \mathrm{~s}^{-1}$ (LL) at $15^{\circ} \mathrm{C}$ and $20^{\circ} \mathrm{C}$, but had no significant effect at $65 \mu$ mol photons $\mathrm{m}^{-2} \mathrm{~s}^{-1}$ (HL). The decrease in growth rate and photosynthesis were, however, not always equivalent; the estimated cellular photosynthesis could be expressed as a linear function of growth rate $(\mathrm{r}=0.9, \mathrm{p}<0.01, \mathrm{n}=5)$ in 5 experiments $\left(15^{\circ} \mathrm{C} \mathrm{LL} \mathrm{Amb}, 20^{\circ} \mathrm{C}\right.$ LL Amb, $20^{\circ} \mathrm{C}$ HL Amb, $20^{\circ} \mathrm{C}$ LL Fut, $20^{\circ} \mathrm{C}$ HL Fut), but the photosynthesis-to-growthrate ratio was much higher in treatments $10^{\circ} \mathrm{C}$ LL $\mathrm{Amb}$ and $15^{\circ} \mathrm{C}$ LL Fut.

\section{Elemental composition and TEP production}

Cell quotas of POC, PON, dry weight, chl $a_{\text {, and }}$ cell normalized TEP concentrations were exceptionally high in the $10^{\circ} \mathrm{C}$ LL Amb and the $15^{\circ} \mathrm{C}$ LL Fut experiments (Fig. 2c), the 2 experiments with the lowest growth rates, which reflects the relatively large cell sizes under these growth conditions. A change in cell size in $15^{\circ} \mathrm{C}$ LL Fut was confirmed by direct determination: cells grown under $15^{\circ} \mathrm{C}$ LL Fut had a diameter of $14.4 \mu \mathrm{m}\left(1170 \mu^{3}\right)$ compared to
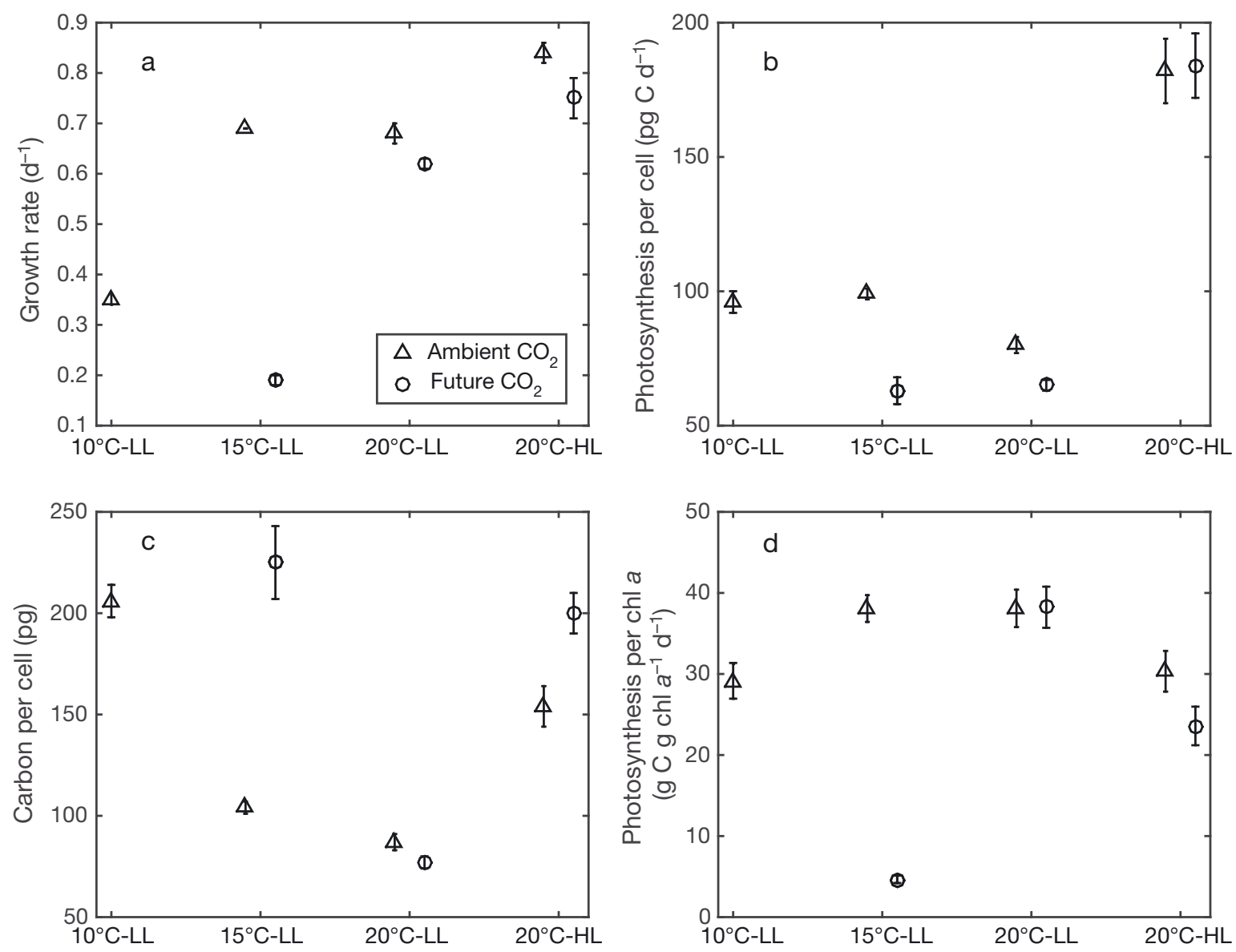

Fig. 2. (a) Growth rates, (b) estimated cellular photosynthesis, (c) POC cell quotas and (d) C:chl a ratios of cultures acclimatized under a range of temperature $\left(10,15\right.$, and $\left.20^{\circ} \mathrm{C}\right)$, light $(\mathrm{HL}=$ high light levels, $\mathrm{LL}=$ low light levels $)$ and $p\left(\mathrm{CO}_{2}\right)(\mathrm{ambient}$ and future) conditions. Error bars are SE 
$11.4 \mu \mathrm{m}\left(581 \mathrm{\mu m}^{3}\right)$ at $15^{\circ} \mathrm{C}$ LL Amb. Generally, cell characteristics depended interactively on growth conditions (Fig. 2c,d, Table 3), with an interactive $p \mathrm{CO}_{2}$ and temperature effect at $35 \mu \mathrm{mol}$ photons $\mathrm{m}^{-2}$ $\mathrm{s}^{-1}\left(15^{\circ} \mathrm{C}\right.$ LL Amb, $15^{\circ} \mathrm{C}$ LL Fut, $20^{\circ} \mathrm{C}$ LL Amb, $20^{\circ} \mathrm{C}$ LL Fut), and a light but no $p \mathrm{CO}_{2}$ effect at $20^{\circ} \mathrm{C}\left(20^{\circ} \mathrm{C}\right.$ LL Amb, $20^{\circ} \mathrm{C}$ LL Fut, $20^{\circ} \mathrm{C}$ HL Amb, $20^{\circ} \mathrm{C}$ HL Fut).

Cell-normalized TEP formation was highest in $15^{\circ} \mathrm{C}$ LL Fut, with intermediate values under HL conditions and in the $10^{\circ} \mathrm{C}$ LL Amb experiment (Table 2). Cell-normalized production of TEP was significantly correlated to POC cell quotas (TEP cell ${ }^{-1}=0.55 \times$ POC cell $\left.{ }^{-1}-4.74\right)(r=0.6, \mathrm{p}<0.001, \mathrm{n}=104)$. Of the 17 data points with residuals $>|50|$ TEP cell ${ }^{-1}, 10$ were from HL experiments $\left(20^{\circ} \mathrm{C} \mathrm{HL} \mathrm{Amb,} \mathrm{or} 20^{\circ} \mathrm{C} \mathrm{HL}\right.$ Fut), and 6 stemmed from the $15^{\circ} \mathrm{C}$ LL Fut experiment, the indication being that irradiance affects the relationship between POC quota and TEP production, and affirming the exceptional status of the $15^{\circ} \mathrm{C}$ LL Fut experiment.

The C:N ratios and the C:chl a ratios were statistically lower in experiments with high irradiance $\left(20^{\circ} \mathrm{C}\right.$ HL Amb, $20^{\circ} \mathrm{C}$ HL Fut), as well as in the $15^{\circ} \mathrm{C}$ LL Fut experiment, compared to the other LL experiments. The very low C:chl a ratio $\left(17 \pm 2 \mathrm{~g} \mathrm{~g}^{-1}\right)$ in the $15^{\circ} \mathrm{C}$ LL Fut treatment is especially noteworthy (Fig. 2d). The C:chl a ratio in the $10^{\circ} \mathrm{C}$ LL Amb experiment was appreciably higher than average (63 \pm 4 ) (Tables $2 \& 3)$.

\section{DISCUSSION}

\section{Growth conditions}

Our experiment was designed to mimic natural fluctuations in growth conditions experienced by coastal cells, while testing the effect of ocean acidification under light- or temperature-limited growth. Within each experiment, temperature remained unchanged, and nutrient concentrations, although variable, were always saturating. Cells experienced fluctuations in the carbonate chemistry and irradiance (due to self-shading) between dilutions, similar to the variable conditions phytoplankton experience during successive bloom and mixing events. All environmental conditions were within currently experienced ranges of coastal diatoms. The TA in experiments was comparable to in situ values at Stearns Wharf pier $\left(34^{\circ} 24^{\prime} 33^{\prime \prime} \mathrm{N}\right.$; $\left.119^{\circ} 41^{\prime} 05^{\prime \prime} \mathrm{W}\right)$, which range between 2241 and $2359 \mu \mathrm{mol} \mathrm{kg}{ }^{-1}$ over the course of a year (U. Passow unpubl.). The experimental TA remained relatively constant over time within each experiment, as would be expected during bloom development and was the same in Amb and Fut treatments, as expected when the ocean acidifies due to increased atmospheric $p \mathrm{CO}_{2}$. DIC and $\mathrm{pH}$ fluctuated during each experiment as they would be expected to fluctuate during alternating bloom development and mixing events, with Fut treatments representing lower average $\mathrm{pH}$ compared to Amb. Whilst the $p \mathrm{CO}_{2}$ conditions in our Fut treatments already occur routinely during upwelling events along the California coast (Feely et al. 2008, Hofmann et al. 2011, Frieder et al. 2012, Johnson et al. 2013), they are also representative of average future conditions of the global ocean. At Stearns Wharf pier, in situ $\mathrm{pH}_{\mathrm{T}}$ varies regularly, between 7.4 and 8.2 within days, and values of 8.6 are reached during dense blooms.

\section{Growth of Thalassiosira weissflogii under temperature or light stress}

An environmental stressor, by definition, produces a negative effect on growth. Whether a specific environmental parameter such as temperature may be considered a stressor for a species thus depends largely on its magnitude relative to the response curve or the optimum growth temperature of that species. For example, an increase in temperature may lead to an increase, a decline, or to no change in the growth rate, depending on whether the initial temperature is sub-optimal, supra-optimal or just below optimal for that species. Accordingly, knowledge of the species-specific response curves to the different environmental parameters including temperature or irradiance is a prerequisite for interpretation of multiple-stressor experiments. The experiments in this study were designed to examine how $T$. weissflogii dealt with mild ocean acidification at suboptimal temperature and light conditions under nutrient-replete growth.

Growth vs. irradiance curves at $15^{\circ} \mathrm{C}$ and $20^{\circ} \mathrm{C}$ cross each other, and are therefore temperature dependent (Fig. 1a). Based on this temperature dependence of the $K_{I}$ of strain 1053 (Fig. 1), it appears that the growth rate of this strain on a $14 \mathrm{~h}$ light:10 $\mathrm{h}$ dark cycle at an irradiance of $35 \mu \mathrm{mol}$ photons $\mathrm{m}^{-2} \mathrm{~s}^{-1}$ is effectively temperature-limited at temperatures $\leq 15^{\circ} \mathrm{C}$, light-limited at temperatures of $20-25^{\circ} \mathrm{C}$, and that no growth is possible at temperatures only a few degrees warmer than $25^{\circ} \mathrm{C}$ (Fig. 1). The saturating light intensity of $T$. weissflogii strains that belong to the Atlantic-Californian cluster is 135-150 $\mu \mathrm{mol}$ photons $\mathrm{m}^{-2} \mathrm{~s}^{-1}$ at $20^{\circ} \mathrm{C}$ for continuous 
exposure (Costello \& Chisholm 1981, Strzepek \& Price 2000, Parker et al. 2004, Finkel et al. 2006). Thus, it may be inferred that $T$. weissflogii's growth rate at $35 \mu \mathrm{mol}$ photons $\mathrm{m}^{-2} \mathrm{~s}^{-1}$ was severely constrained by temperature at $5^{\circ} \mathrm{C}, 10^{\circ} \mathrm{C}$, and $25^{\circ} \mathrm{C}$, whereas at $20^{\circ} \mathrm{C}$, growth rates at ambient $\mathrm{CO}_{2}$ were severely light limited at $35 \mu \mathrm{mol}$ photons $\mathrm{m}^{-2} \mathrm{~s}^{-1}$ and mildly light limited at $65 \mu \mathrm{mol}$ photons $\mathrm{m}^{-2} \mathrm{~s}^{-1}$; both growth rate and estimated photosynthesis increased as irradiance increased from $35 \mu \mathrm{mol}$ photons $\mathrm{m}^{-2} \mathrm{~s}^{-1}$ to $65 \mu \mathrm{mol}$ photons $\mathrm{m}^{-2} \mathrm{~s}^{-1}$ (Table 2). At $15^{\circ} \mathrm{C}$, neither an increase in temperature nor irradiance alone led to an increase in growth rate (Table 2), suggesting that growth rate was co-limited by both light and temperature in $15^{\circ} \mathrm{C} \mathrm{LL} \mathrm{Amb.}$

\section{Growth response of Thalassiosira weissflogii to elevated $\mathrm{pCO}_{2}$}

In our experiments elevated $p \mathrm{CO}_{2}$ had no significant impact on growth rate or estimated cellular photosynthesis at $65 \mu \mathrm{mol}$ photons $\mathrm{m}^{-2} \mathrm{~s}^{-1}\left(20^{\circ} \mathrm{C}\right.$ $\mathrm{HL})$; conditions that exerted only mild light limitation (Tables $2 \& 4$ ). $p \mathrm{CO}_{2}$ perturbations simulating future ocean acidification conditions under saturating irradiance levels $\left(\geq 100 \mu \mathrm{mol}\right.$ photons $\mathrm{m}^{-2} \mathrm{~s}^{-1}$ ) and nutrient-replete conditions at $15^{\circ} \mathrm{C}$ and $20^{\circ} \mathrm{C}$ also showed no significant $p \mathrm{CO}_{2}$ impact on the growth rates of T. weissflogii (Burkhardt et al. 1999, Reinfelder 2012, Taucher et al. 2015). Increased $p \mathrm{CO}_{2}$ allows many diatom species to down-regulate their carbon concentrating mechanism (CCM), freeing resources for processes including growth, productivity, and enzyme synthesis ( $\mathrm{Li}$ \& Campbell 2013, Wu et al. 2014), the result being an increase in their growth rate (Riebesell et al. 1993, WolfGladrow et al. 1999, McCarthy et al. 2012, Wu et al. 2014). However, mechanisms of carbon acquisition and carbon concentrating mechanisms vary widely between species (Trimborn et al. 2009), and a negative response and no response to an increase in $p \mathrm{CO}_{2}$ are also common (Kim et al. 2006, Feng et al. 2009, Low-Decarie et al. 2011, Gao et al. 2012a). Carbon acquisition of $T$. weissflogii differs from that of many other species (Burkhardt et al. 2001). The fact that $T$. weissflogii uses a combination of biochemical and biophysical CCMs, thereby reducing potential negative impacts of photorespiration on growth rate (Roberts et al. 1997, Milligan et al. 2009), may explain the lack of a positive response to elevated $p \mathrm{CO}_{2}$ under near-optimal growth conditions (Yang \& Gao 2012).
However, both photosynthesis and growth rate were down-regulated under elevated $p \mathrm{CO}_{2}$ when light limiting $\left(20^{\circ} \mathrm{C} \mathrm{LL}\right)$, or light- and temperaturelimiting conditions $\left(15^{\circ} \mathrm{C} \mathrm{LL}\right)$ prevailed. Moreover, the decrease in growth rate when $p \mathrm{CO}_{2}$ was elevated was precipitous under light- and temperaturelimited growth $\left(15^{\circ} \mathrm{C} \mathrm{LL}\right)$. Growth rates at $15^{\circ} \mathrm{C} \mathrm{LL}$ were low $\left(0.2 \mathrm{~d}^{-1}\right)$ for $2-4$ generations under both ambient and elevated $p \mathrm{CO}_{2}$ conditions, but thereafter cells acclimatized under ambient $p \mathrm{CO}_{2}$ conditions $\left(15^{\circ} \mathrm{C} \mathrm{LL} \mathrm{Amb),} \mathrm{with} \mathrm{growth} \mathrm{rates} \mathrm{increasing} \mathrm{to}\right.$ the same level $\left(0.7 \mathrm{~d}^{-1}\right)$ as at $20^{\circ} \mathrm{C}$ LL Amb. Potentially, a higher concentration of enzymes compensated for temperature-dependent, reduced enzyme activity, allowing for the increased growth rate at $15^{\circ} \mathrm{C}$ after acclimatization (Davison 1991, Thompson et al. 1992, Falkowski \& Raven 1997). However, it is noteworthy that the time period required for acclimatization was weeks rather than days, which questions the common practice of acclimatizing cultures for 5-8 d to experimental conditions.

In contrast, growth rate remained low under future conditions $\left(15^{\circ} \mathrm{C}\right.$ LL Fut), although estimated cellular photosynthesis was comparable to that at $20^{\circ} \mathrm{C} \mathrm{LL}$ Fut (Table 2). The amount of carbon produced per cell at $15^{\circ} \mathrm{C}$ LL Fut was more than twice the amount produced by cells at $15^{\circ} \mathrm{C} \mathrm{LL} \mathrm{Amb,} 20^{\circ} \mathrm{C} \mathrm{LL} \mathrm{Amb,} \mathrm{or}$ $20^{\circ} \mathrm{C}$ LL Fut. This decoupling between growth rate and photosynthesis at $15^{\circ} \mathrm{C}$ LL Fut led to larger cells and increased production of TEP, i.e. an increased production of extracellular carbon. The very high chl a content of these cells ( $\mathrm{C}: \mathrm{chl} a=17 \pm 2 \mathrm{~g} \mathrm{~g}^{-1}$ ) may be interpreted as compensation for an increased energy demand due to internal acid-base perturbations caused by the elevated $p \mathrm{CO}_{2}$. Ocean acidification conditions lead to changes in energetics associated not only with the down-regulation of the CCMs, but also with up-regulated costs to re-equilibrate the disturbed acid-base balance (Gao et al. 2012b). Increased light harvesting capabilities may be the response to additional energy demands (Gao et al. 2012b). It appears that physiological acclimatization, which permitted higher growth rate at $15^{\circ} \mathrm{C} \mathrm{LL} \mathrm{Amb,}$ was not achievable under elevated $p \mathrm{CO}_{2}$, likely due to the additional energy needed to cope with the acid-base perturbation. In summary, we suggest that under light- and temperature-limited growth, even mild ocean acidification conditions acted as an additional stressor requiring additional energy. High additional energy needs meant firstly, that cellular chl a was increased, allowing photosynthesis to remain high, and secondly, acclimatization to low temperature was prevented, keeping growth rates 
low. The decoupling between growth rate and photosynthesis led to larger cell size and increased excretion.

A similar negative $p \mathrm{CO}_{2}$ effect on growth rate at sub-saturating irradiance, but not at saturating light was also observed for Chaetoceros muelleri (diatom) (Ihnken et al. 2011), Emiliania huxleyi (coccolithophore) (Feng et al. 2008), and Proboscia alata (diatom) (Hoogstraten et al. 2012). Under sub-saturating light conditions, Proboscia alata cells grown at elevated $p \mathrm{CO}_{2}$ were larger, had higher chl $a$ and POC cell quotas, but grew at reduced growth rates compared to cells at ambient $p \mathrm{CO}_{2}$. These $p \mathrm{CO}_{2}$ effects were not apparent during growth at saturating light levels. Based on microscopic observations, Hoogstraten et al. (2012) speculated that low pH led to the deterioration of the organic layer protecting the silica frustule. The fact that the repair or maintenance of the frustule and organic layer would require energy could explain why cells grown at higher light did not show the same response to elevated $p \mathrm{CO}_{2}$. However, little is known about maintenance activities for the outer organic coating of diatoms, and no evidence exists for a frustule repair mechanism.

\section{Decoupling of photosynthesis and growth rate}

Decoupling between photosynthesis and growth rate analogous to the results at $15^{\circ} \mathrm{C}$ LL Fut was also observed, albeit to a lesser degree, in the temperature-limited experiment $\left(10^{\circ} \mathrm{C} \mathrm{LL} \mathrm{Amb).} \mathrm{Estimated}\right.$ photosynthesis at $10^{\circ} \mathrm{C}$ was comparable to that at $15^{\circ} \mathrm{C}$, but growth rate at $10^{\circ} \mathrm{C}$ was about half that at $15^{\circ} \mathrm{C}\left(15^{\circ} \mathrm{C} \mathrm{LL} \mathrm{Amb}\right)$. As a result, cell size and cellular TEP production were both elevated at $10^{\circ} \mathrm{C}$ compared to $15^{\circ} \mathrm{C}$ (LL Amb). Higher cell quotas associated with larger cells as a function of reduced growth temperature is commonly observed in diatoms (Montagnes \& Franklin 2001). The relatively high $\mathrm{C}$ :chl a ratio at $10^{\circ} \mathrm{C} \mathrm{LL} \mathrm{Amb} \mathrm{(Table} \mathrm{2)} \mathrm{is} \mathrm{consistent}$ with the interpretation that growth at $10^{\circ} \mathrm{C} \mathrm{LL} \mathrm{Amb}$ was limited by temperature, but not by light. Apparently the irradiance of $35 \mu \mathrm{mol}$ photons $\mathrm{m}^{-2} \mathrm{~s}^{-1}$ that was growth-limiting at warmer temperatures was near optimal for growth at $10^{\circ} \mathrm{C}$. The response to suboptimal temperature for growth further shows that very different stressors or combination of stressors can lead to disequilibria between photosynthesis and cell division.

Increased TEP production, that is release of carbon-rich organic substances, may be attributed to an imbalance in which the potential for energy pro- duction and carbon assimilation exceeds the potential for cell division. Increased $p \mathrm{CO}_{2}$ has been suggested to lead to increased TEP formation (Engel et al. 2004). However, later studies failed to show a link between TEP formation and $p \mathrm{CO}_{2}$ (Egge et al. 2009). We suggest that this discrepancy may be resolved by considering interactions of multiple stressors. The release of TEP under elevated $p \mathrm{CO}_{2}$ is known to be enhanced in association with nitrogen limitation, but not when nutrients were nonlimiting (Giordano et al. 1994, Kim et al. 2011, Taucher et al. 2015). We suggest that disequilibrium conditions between carbon acquisition and growth rate could just as easily be caused by supra-saturating light (excess energy) or elevated $p \mathrm{CO}_{2}$ as by sub-optimal temperatures or nutrient limitation, which inhibit division rates.

\section{Multiple-stressor effects}

Our results clearly show that the effects of $p \mathrm{CO}_{2}$ on phytoplankton depend interactively on growth conditions as well as on the CCM of a species. The observed $p \mathrm{CO}_{2}$ effect on growth and cell quotas under light- and temperature-limited growth contrasts with the findings that $T$. weissflogii (unknown strain and CCMP 1336, respectively) is only impacted by $p \mathrm{CO}_{2}$ below 380 ppm (Burkhardt et al. 1999, Reinfelder 2012) and emphasizes that the effect of $p \mathrm{CO}_{2}$ depends on the presence or absence of additional environmental stressors (Table 4). Elevated $p \mathrm{CO}_{2}$ led to reduced growth rate of $T$. weissflogii under light- and temperature-limited growth conditions, but in the absence of other stressors, cells mediated the impact of higher $p \mathrm{CO}_{2}$ without visible effects on growth or photosynthesis. Only extreme $p \mathrm{CO}_{2}$ perturbations, not expected in the future ocean, acted as stressors by themselves (Table 4). Moreover, the response of T. weissflogii to elevated $p \mathrm{CO}_{2}$ differs from that of many other diatoms; growth rates of T. pseudonana and Skeletonema costatum, for example, were enhanced under high $p \mathrm{CO}_{2}$ and sub-saturating light, and unaffected or decreased at saturating or suprasaturating light levels (Cullen et al. 1992, Gao et al. 2012a, Yang \& Gao 2012, Li \& Campbell 2013, Wu et al. 2014). These species-specific differences in the response to ocean acidification are likely the result of different CCMs (Burkhardt et al. 2001, Trimborn et al. 2009).

Our results further suggest that decoupling between photosynthesis and growth rate may be a 
Table 4. Percentile decrease in growth rates $(\Delta \mu)$ of Thalassiosira weissflogii due to elevated $\mathrm{CO}_{2}$ partial pressure $\left(p \mathrm{CO}_{2}\right)$ (comparison between ambient [Amb] and future [Fut] treatments) and assessment of the presence of environmental stressors. $T$ = temperature. T. weissflogii Strains CCMP 1053 and CCMP 1336 most likely belong to the same species, the strain isolated off Japan is likely from a different species (Sorhannus et al. 2010). No nutrient limitation was observed in any of the listed experiments. NS: no significant change in $\Delta \mu$

\begin{tabular}{|c|c|c|c|c|c|c|}
\hline $\begin{array}{l}\mathrm{T} \\
\left({ }^{\circ} \mathrm{C}\right)\end{array}$ & $\begin{array}{l}\text { Light } \\
\left(\mu \mathrm{mol} \mathrm{\textrm {m } ^ { - 2 }} \mathrm{d}^{-1}\right)\end{array}$ & $\begin{array}{l}\text { Photoperiod } \\
\text { (h) }\end{array}$ & $\begin{array}{c}\Delta \mu \\
(\%)\end{array}$ & Growth conditions & CCMP & Reference \\
\hline 15 & 35 & 14 & 72 & Light and temperature limited $^{\mathrm{d}}$ & 1053 & This study \\
\hline 20 & 35 & 14 & 9 & Light limitation & 1053 & This study \\
\hline 20 & 65 & 14 & NS & Mild light limitation & 1053 & This study \\
\hline 15 & 50 & 14 & NS & Mild light and temperature limitation ${ }^{\mathrm{d}}$ & 1336 & Seebah et al. (2014) \\
\hline 20 & 50 & 14 & NS & Mild light limitation & 1336 & Seebah et al. (2014) \\
\hline $15^{\mathrm{a}}$ & 100 & 14 & NS & No light $^{\mathrm{c}}$, but mild temperature limitation ${ }^{\mathrm{d}}$ & 1053 & Taucher et al. (2015) \\
\hline 20 & 100 & 14 & NS & No limitation ${ }^{\mathrm{c}}$ & 1053 & Taucher et al. (2015) \\
\hline $15^{\mathrm{b}}$ & 150 & 18,24 & NS & No limitation ${ }^{\mathrm{c}, \mathrm{e}}$ & Unknown & Burkhardt et al. (1999) \\
\hline 18 & 200 & 12 & NS & No limitation $^{\mathrm{c}}$ & 1336 & Reinfelder (2012) \\
\hline 25 & 50 & 24 & 50 & $\begin{array}{l}\text { Extreme } p \mathrm{CO}_{2} \text { perturbation } \\
(200000 \mathrm{ppm})\end{array}$ & $\begin{array}{l}\text { Isolated off } \\
\text { Japan }\end{array}$ & Ishida et al. (2000) \\
\hline \multicolumn{7}{|c|}{$\begin{array}{l}\text { aOnly the nutrient replete phase of the batch experiment was considered } \\
{ }^{\mathrm{b}} \mathrm{pH} \text { and total alkalinity perturbation rather than a dissolved inorganic carbon perturbation } \\
{ }^{\mathrm{c}} \text { Absence of light limitation was assumed at } \geq 100 \mu \mathrm{mol} \mathrm{m}^{-2} \mathrm{~s}^{-1} \text { for } \geq 14 \mathrm{~h} \text { because at } 20^{\circ} \mathrm{C} \text { growth rate under those irradiance } \\
\text { levels was similar to that at } 135 \mu \mathrm{mol} \text { photons } \mathrm{m}^{-1} \mathrm{~s}^{-1} \\
{ }^{\mathrm{d}} \text { Temperature limitation was assumed because increased temperature led to an increase in growth rate } \\
{ }^{\mathrm{e}} \text { Growth rate }=1.5 \mathrm{~d}^{-1} \text {, suggesting the absence of significant growth limitation at this light and temperature combination }\end{array}$} \\
\hline
\end{tabular}

common response of phytoplankton to different types of stressors or combinations of stressors. One can speculate that it is advantageous for a species to produce larger cells when growth conditions constrain division rate more than photosynthesis. As soon as growth conditions improve, a larger cell may have faster growth rates, or a more immediate growth response, potentially translating into a competitive advantage. Cell size may also be coupled to sexual reproduction, but asexual cell size changes are possible (Armbrust \& Chisholm 1992). Excretion of organic matter, including TEPprecursors, may be interpreted as the safety valve enabling the removal of excess photosynthate, thereby facilitating the decoupling between photosynthesis and growth rates. A certain degree of decoupling between growth rate and photosynthesis may in turn provide cells with increased opportunities to rapidly respond to changing growth conditions and acclimatize to specific stressors in an optimized fashion.

Acknowledgements. We thank Caitlin Fairfield and Julia Sweet for their careful work with the cultures. This research was funded by grants from the National Science Foundation OCE-0926711 and OCE-1041038 to UP. The data is stored at the NSF data site BCO-DMO (Biological and Chemical Oceanography Data Management Office) under doi: 10. 1575/1912/7689.

\section{LITERATURE CITED}

Antoine D, Morel A, Gordon HR, Banzon VF, Evans RH (2005) Bridging ocean color observations of the 1980s and 2000s in search of long-term trends. J Geophys Res C 110:C06009, doi:10.1029/2004JC002620

Armbrust EV, Chisholm SW (1992) Patterns of cell size change in a marine centric diatom: variability evolving from clonal isolates. J Phycol 28:146-156

Bannister TT, Laws EA (1980) Modeling phytoplankton carbon metabolism. In: Falkowski P (ed) Primary productivity in the sea. Environmental Science Research, Vol 19. Plenum Press, New York, NY

> Boyce DG, Lewis MR, Worm B (2010) Global phytoplankton decline over the past century. Nature 466:591-596

> Boyd PW, Strzepek R, Fu FX, Hutchins DA (2010) Environmental control of open-ocean phytoplankton groups: Now and in the future. Limnol Oceanogr 55:1353-1376

Brewer PG, Bradshow AL, Williams RT (1986) Measurement of total carbon dioxide and alkalinity in the North Atlantic Ocean in 1981. In: Trabalka JR, Reichle DE (eds) The changing carbon cycle: A global analysis. Springer Science+Business Media, New York, NY, p 348-370

Burkhardt S, Zondervan I, Riebesell U (1999) Effect of $\mathrm{CO}_{2}$ concentration on $\mathrm{C}: \mathrm{N}$ :P ratio in marine phytoplankton: a species comparison. Limnol Oceanogr 44:683-690

> Burkhardt S, Amoroso G, Riebesell U, Sultemeyer D (2001) $\mathrm{CO}_{2}$ and $\mathrm{HCO}_{3}$ uptake in marine diatoms acclimated to different $\mathrm{CO}_{2}$ concentrations. Limnol Oceanogr 46: 1378-1391

> Caperon J (1967) Population growth in micro-organisms limited by food supply. Ecology 48:715-721

Chappell PD, Whitney LP, Haddock TL, Menden-Deuer S, Roy EG, Wells ML, Jenkins BD (2013) Thalassiosira spp. 
community composition shifts in response to chemical and physical forcing in the northeast Pacific Ocean. Front Microbiol 4:273

Clayton TD, Byrne RH (1993) Spectrophotometric seawater $\mathrm{pH}$ measurements: total hydrogen ion concentration scale calibration of $m$-cresol purple and at sea results. Deep-Sea Res I 40:2115-2129

- Corzo A, Morillo JA, Rodriguez S (2000) Production of transparent exopolymer particles (TEP) in cultures of Chaetoceros calcitrans under nitrogen limitation. Aquat Microb Ecol 23:63-72

Costello J, Chisholm SW (1981) The influence of cell size on the growth rate of Thalassiosira weissflogii. J Plankton Res 3:415-419

Cullen JJ, Lewis MR, Davis CO, Barber RT (1992) Photosynthetic characteristics and estimated growth rates indicate grazing is the proximate control of primary production in the Equatorial Pacific. J Geophys Res C 97:639-654

- Davison IR (1991) Environmental effects on algal photosynthesis: Temperature. J Phycol 27:2-8

Dickson AG, Millero FJ (1987) A comparison of the equilibrium constants for the dissociation of carbonic acid in seawater media. Deep-Sea Res A 34:1733-1743

Dickson AG, Sabine CL, Christian JR (eds) (2007) Guide to best practices for $\mathrm{CO}_{2}$ measurements. PICES Spec Publ 3:1-191

Egge JK, Thingstad TF, Larsen A, Engel A, Wohlers J, Bellerby RGJ, Riebesell U (2009) Primary production during nutrient-induced blooms at elevated $\mathrm{CO}_{2}$ concentrations. Biogeosciences 6:877-885

Engel A, Passow U (2001) Carbon and nitrogen content of transparent exopolymer particles (TEP) in relation to their Alcian Blue adsorption. Mar Ecol Prog Ser 219:1-10

Engel A, Delille B, Jacquet S, Riebesell U, Rochelle-Newall E, Terbruggen A, Zondervan I (2004) Transparent exopolymer particles and dissolved organic carbon production by Emiliania huxleyi exposed to different $\mathrm{CO}_{2}$ concentrations: a mesocosm experiment. Aquat Microb Ecol 34:93-104

Falkowski P, Raven JA (1997) Aquatic photosynthesis. Blackwell Scientific, Oxford

Fangue N, O'Donnell M, Sewell M, Matson P, MacPherson A, Hofmann G (2010) A laboratory-based experimental system for the study of ocean acidification effects on marine invertebrate larvae. Limnol Oceanogr Methods 8:441-452

Feely RA, Sabine CL, Hernandez-Ayon JM, Ianson D, Hales B (2008) Evidence for upwelling of corrosive 'acidified' water onto the continental shelf. Science 320:1490-1492

Feng Y, Warner ME, Zhang Y, Sun J, Fu FX, Rose JM, Hutchins DA (2008) Interactive effects of increased $\mathrm{pCO}_{2}$, temperature and irradiance on the marine coccolithophore Emiliania huxleyi (Prymnesiophyceae). Eur J Phycol 43:87-98

> Feng Y, Hare C, Leblanc K, Rose J and others (2009) Effects of increased $\mathrm{pCO}_{2}$ and temperature on the North Atlantic spring bloom. I. The phytoplankton community and biogeochemical response. Mar Ecol Prog Ser 388: 13-25

> Finkel ZV, Quigg A, Raven JA, Reinfelder JR, Schofield OE, Falkowski PG (2006) Irradiance and the elemental stoichiometry of marine phytoplankton. Limnol Oceanogr 51:2690-2701

Frieder C, Nam S, Martz TR, Levin LA (2012) High temporal and spatial variability of dissolved oxygen and $\mathrm{pH}$ in a nearshore California kelp forest. Biogeosciences 9: 3917-3930

Fryxell GA, Hasle GR (1977). The genus Thalassiosira: some species with a modified ring of central strutted processes. Nova Hedwigia Beih 54: 67-98

Fukao T, Kimoto K, Kotani Y (2012) Effect of temperature on cell growth and production of transparent exopolymer particles by the diatom Coscinodiscus granii isolated from marine mucilage. J Appl Phycol 24:181-186

Gao K, Xu J, Gao G, Li Y and others (2012a) Rising $\mathrm{CO}_{2}$ and increased light exposure synergistically reduce marine primary productivity. Nat Clim Change 2:519-523

Gao KS, Helbling EW, Hader DP, Hutchins DA (2012b) Responses of marine primary producers to interactions between ocean acidification, solar radiation, and warming. Mar Ecol Prog Ser 470:167-189

> Giordano M, Davis JS, Bowes G (1994) Organic carbon release by Dunaliella salina (Chlorophyta) under different growth conditions of $\mathrm{CO}_{2}$, nitrogen, and salinity. J Phycol 30:249-257

Gran G (1952) Determinations of the equivalence point in potentiometric titrations of seawater with hydrochloric acid. Oceanol Acta 5:209-218

Guillard RRL (1975) Culture of phytoplankton for feeding marine invertebrates. In: Smith WL, Chanley MH (eds) Culture of marine invertebrate animals. Plenum Press, New York, NY, p 29-60

Halac SR, Villafañe VE, Helbling EW (2010) Temperature benefits the photosynthetic performance of the diatoms Chaetoceros gracilis and Thalassiosira weissflogii when exposed to UVR. J Photochem Photobiol B 101:196-205

Ho TY, Quigg A, Finkel ZV, Milligan AJ, Wyman K, Falkowski PG, Morel FMM (2003) The elemental composition of some marine phytoplankton. J Phycol 39: 1145-1159

Hofmann GE, Smith JE, Johnson KS, Send U and others (2011) High frequency dynamics of ocean pH: a multiecosystem comparison. PLoS ONE 6:e28983

Hoogstraten A, Timmermans KR, de Baar HJW (2012) Morphological and physiological effects in Proboscia alata (Bacillariophyceae) grown under different light and $\mathrm{CO}_{2}$ conditions of the modern Southern Ocean. J Phycol 48: 559-568

Hoppe CJM, Langer G, Rokitta SD, Wolf-Gladrow D, Rost B (2012) Implications of observed inconsistencies in carbonate chemistry measurements for ocean acidification studies. Biogeosciences 9:2401-2405

- Ihnken S, Roberts S, Beardall J (2011) Differential responses of growth and photosynthesis in the marine diatom Chaetoceros muelleri to $\mathrm{CO}_{2}$ and light availability. Phycologia 50:182-193

Ishida Y, Hiragushi N, Kitaguchi H, Mitsutani A, Nagai S, Yoshiura K (2000) A highly $\mathrm{CO}_{2}$-tolerant diatom, Thalassiosira weissflogii $\mathrm{H} 1$, enriched from coastal sea, and its fatty acid composition. Fish Sci 66:655-659

Johnson ZI, Wheeler BJ, Blinebry SK, Carlson CM, Ward CS, Hunt DE (2013) Dramatic variability of the carbonate system at a temperate coastal ocean site (Beaufort, North Carolina, USA) is regulated by physical and biogeochemical processes on multiple timescales. PLoS ONE 8: e85117

Katayama T, Murata A, Taguchi S (2012) Responses of pigment composition of the marine diatom Thalassiosira weissflogii to silicate availability during dark survival and recovery. Plankton Benthos Res 7:158 
Kepkay PE, Johnson BD (1989) Coagulation on bubbles allows microbial respiration of oceanic dissolved organic carbon. Nature 338:63-65

Kim JM, Lee K, Shin K, Kang JH and others (2006) The effect of seawater $\mathrm{CO}_{2}$ concentration on growth of a natural phytoplankton assemblage in a controlled mesocosm experiment. Limnol Oceanogr 51:1629-1636

- Kim JM, Lee K, Shin K, Yang EJ, Engel A, Karl DM, Kim HC (2011) Shifts in biogenic carbon flow from particulate to dissolved forms under high carbon dioxide and warm ocean conditions. Geophys Res Lett 38, L08612, doi:10.1029/2011GL047346

> Laney S, Letelier R, Abbott M (2005) Parameterizing the natural fluorescence kinetics of Thalassiosira weissflogii. Limnol Oceanogr 50:1499-1510

> Laws EA, Bannister TT (1980) Nutrient- and light-limited growth of Thalassiosira fluviatilis in continuous culture, with implications for phytoplankton growth in the ocean. Limnol Oceanogr 25:457-473

Laws EA, Sakshaug E, Babin M, Dandonneau Y and others (2002) Photosynthesis and primary productivity in marine ecosystems: practical aspects and application of techniques. JGOFS Report No. 36. JGOFS International Project Office, Bergen, Norway

Lefebvre S, Benner I, Stillmann J, Parker A and others (2012) Nitrogen source and $p \mathrm{CO}_{2}$ synergistically affect carbon allocation, growth and morphology of the coccolithophore Emiliania huxleyi: potential implications of ocean acidification for the carbon cycle. Glob Change Biol 18: 493-503

Lewis E, Wallace DWR (1998) Program developed for $\mathrm{CO}_{2}$ system calculations. ORNL/CDIAC-105. Carbon Dioxide Information Analysis Center, Oak Ridge National Laboratory, Oak Ridge, TN

> Li G, Campbell D (2013) Rising $\mathrm{CO}_{2}$ interacts with growth light and growth rate to alter photosystem II photoinactivation of the coastal diatom Thalassiosira pseudonana. PLoS ONE 8:e55562

Liu S, Guo Z, Li T, Huang H, Lin S (2011) Photosynthetic efficiency, cell volume, and elemental stoichiometric ratios in Thalassirosira weissflogii under phosphorus limitation. Chin J Oceanol Limnol 29:1048-1056

> Low-Decarie E, Fussmann GF, Bell G (2011) The effect of elevated $\mathrm{CO}_{2}$ on growth and competition in experimental phytoplankton communities. Glob Change Biol 17: 2525-2535

> McCarthy A, Rogers SP, Duffy SJ, Campbell DA (2012) Elevated carbon dioxide differentially alters the photophysiology of Thalassiosira pseudonana (Bacillariophyceae) and Emiliania huxleyi (Haptophyta). J Phycol 48:635-646

McLachlan J, McInnes AG, Falk M (1965) Studies on the chitan (chitin:poly-N-acetylglucosamine) fibers of the diatom Thalassiosira fluviatilis Hustedt. I. Production and isolation of chitan fibers. Can J Bot 43:707-713

> Milligan AJ, Mioni CE, Morel FMM (2009) Response of cell surface $\mathrm{pH}$ to $\mathrm{pCO}_{2}$ and iron limitation in the marine diatom Thalassiosira weissflogii. Mar Chem 114:31-36

Montagnes DJS, Franklin DJ (2001) Effect of temperature on diatom volume, growth rate, and carbon and nitrogen content: reconsidering some paradigms. Limnol Oceanogr 46:2008-2018

> Mopper K, Zhou JA, Ramana KS, Passow U, Dam HG, Drapeau DT (1995) The role of surface-active carbohydrates in the flocculation of a diatom bloom in a meso- cosm. Deep-Sea Res II 42:47-73

Murphy AM, Cowles TJ (1997) Effects of darkness on multiexcitation in vivo fluorescence and survival in a marine diatom. Limnol Oceanogr 42:1444-1453

> Parker SM, Armbrust EV, Piovia-Scott J, Keil RG (2004) Induction of photorespiration by light in the centric diatom Thalassiosira weissflogii (Bacillariophyceae): Molecular characterization and physiological consequences. J Phycol 40:557-567

> Passow U (2000) Formation of transparent exopolymer particles, TEP, from dissolved precursor material. Mar Ecol Prog Ser 192:1-11

Passow U (2012) The abiotic formation of TEP under different ocean acidification scenarios. Mar Chem 128-129: $72-80$

Passow U, Alldredge AL (1995) A dye-binding assay for the spectrophotometric measurement of transparent exopolymer particles (TEP). Limnol Oceanogr 40:1326-1335

Passow U, Carlson C (2012) The biological pump in a high $\mathrm{CO}_{2}$ world. Mar Ecol Prog Ser 470:249-271

Piontek J, Haendel N, Langer G, Wohlers J, Riebesell U, Engel A (2009) Effects of rising temperature on the formation and microbial degradation of marine diatom aggregates. Aquat Microb Ecol 54:305-318

Price NM (2005) The elemental stoichiometry and composition of an iron-limited diatom. Limnol Oceanogr 50: 1159-1171

Redfield AC, Ketchum BM, Richards FA, Hill MN (1963) The influence of organisms on the composition of sea-water. In: Hill MN (ed) The Sea, Vol 2. Wiley, New York, NY

Reinfelder JR (2012) Carbon dioxide regulation of nitrogen and phosphorus in four species of marine phytoplankton. Mar Ecol Prog Ser 466:57-67

Riebesell U, Wolf-Gladrow DA, Smetacek V (1993) Carbon dioxide limitation of marine phytoplankton growth rates. Nature 361:249-251

Riebesell U, Schulz KG, Bellerby RGJ, Botros M and others (2007) Enhanced biological carbon consumption in a high $\mathrm{CO}_{2}$ ocean. Nature 450:545-548

Riebesell U, Fabry VJ, Hansson L, Gattuso JP (eds) (2010) Guide to best practices for ocean acidification research and data reporting, Publications Office of the European Union, Luxembourg

Roberts SB, Lane TW, Morel FMM (1997) Carbonic anhydrase in the marine diatom Thalassiosira weissflogii (Bacillariophyceae). J Phycol 33:845-850

Roberts K, Granum E, Leegood R, Raven JA (2007) C3 and C4 pathways of photosynthetic carbon assimilation in marine diatoms are under genetic, not environmental, control. Plant Physiol 145:230-235

> Rost B, Zondervan I, Wolf-Gladrow D (2008) Sensitivity of phytoplankton to future changes in ocean carbonate chemistry: current knowledge, contradictions and research directions. Mar Ecol Prog Ser 373:227-237

> Seebah S, Fairfield C, Ullrich MS, Passow U (2014) Aggregation and sedimentation of Thalassiosira weissflogii (diatom) in a warmer and more acidified future ocean. PLoS ONE 9:e112379

Sorhannus U, Ortiz JD, Wolf M, Fox MG (2010) Microevolution and speciation in Thalassiosira weissflogii (Bacillariophyta). Protist 161:237-249

Strickland JDH (1972) A practical handbook of seawater analysis. Bull Fish Res Board Can 167

Strzepek RF, Price NM (2000) Influence of irradiance and temperature on the iron content of the marine diatom 
Thalassiosira weissflogii (Bacillariophyceae). Mar Ecol Prog Ser 206:107-117

Sun J, Hutchins DA, Feng Y, Seubert EL, Caron DA, Fu FX (2011) Effects of changing $p \mathrm{CO}_{2}$ and phosphate availability on domoic acid production and physiology of the marine harmful bloom diatom Pseudo-nitzschia multiseries. Limnol Oceanogr 56:829-840

Sunda WG, Huntsman SA (1997) Interrelated influence of iron, light and cell size on marine phytoplankton growth. Nature 390:389-392

Sunda WG, Huntsman SA (2004) Relationships among photoperiod, carbon fixation, growth, chlorophyll a, and cellular iron and zinc in a coastal diatom. Limnol Oceanogr 49:1742-1753

Taucher J, Jones J, James A, Brzezinski MA, Carlson CA, Riebesell U, Passow U (2015) Combined effects of $\mathrm{CO}_{2}$ and temperature on carbon uptake and partitioning by the marine diatoms Thalassiosira weissflogii and Dactyliosolen fragilissimus. Limnol Oceanogr 60:901-919

Thompson PA, Guo M-X, Harrison PJ (1992) Effects of variation in temperature. I. On biochemical composition of eight species of marine phytoplankton. J Phycol 28:481-488

Timmermans KR, van der Wagt B, de Baar HJW (2004)

Editorial responsibility: Steven Lohrenz,

New Bedford, Massachusetts, USA
Growth rates, half-saturation constants, and silicate, nitrate, and phosphate depletion in relation to iron availability of four large open-ocean diatoms from the Southern Ocean. Limnol Oceanogr 49:2141-2151

Trimborn S, Wolf-Gladrow D, Richter KU, Rost B (2009) The effect of $\mathrm{pCO}_{2}$ on carbon acquisition and intracellular assimilation in four marine diatoms. J Exp Mar Biol Ecol 376:26-36

Vrieling EG, Poort L, Beelen TPM, Gieskes WWC (1999) Growth and silica content of the diatoms Thalassiosira weissflogii and Navicula salinarum at different salinities and enrichments with aluminium. Eur J Phycol 34: 307-316

Wolf-Gladrow DA, Riebesell U, Burkhardt S, Bijma J (1999) Direct effects of $\mathrm{CO}_{2}$ concentration on growth and isotopic composition of marine plankton. Tellus B Chem Phys Meterol 51:461-476

> Wu Y, Campbell DA, Irwin AJ, Suggett DJ, Finkel ZV (2014) Ocean acidification enhances the growth rate of larger diatoms. Limnol Oceanogr 59:1027-1034

Yang G, Gao K (2012) Physiological responses of the marine diatom Thalassiosira pseudonana to increased $p \mathrm{CO}_{2}$ and seawater acidity. Mar Environ Res 79:142-151

Submitted: July 13, 2015; Accepted: November 1, 2015 Proofs received from author(s): November 30, 2015 